\title{
VII Conference/Festival Latin American Theatre Today March 26-29, 2008 - Blacksburg, Virginia
}

\section{Timothy G. Compton}

Because the seventh version of the Latin American Theatre Today conference/festival was held on the campus of Virginia Tech, participants learned that the school's mascot, a hokie, is a fierce wild turkey. Jacqueline Bixler, who has claimed Virginia Tech as her academic home for several decades, spearheaded the organization and orchestration of festivities, which included securing 15 different sponsorships, bringing performers from all over the Americas, arranging for space, transportation and food, and disseminating information. This edition of LATT had as its theme "Re-thinking 'Latin American' Theatre." It featured 29 sessions of scholarly papers, four workshops, several playwright roundtables, a pair of plenary sessions, an homage to Emilio Carballido, sessions on (and sales of) books, journals, and DVDs, seven main stage theatre productions, several staged readings, and at least one clandestine play performance. The abundance of offerings made it absolutely impossible to take in everything. Events were scheduled from 8:00 AM until late at night, usually with more than one event at a time. No one seemed happier than George Woodyard, who, at least on the surface, had no official role in the undertaking other than to moderate a session.

Over 100 scholars presented papers on topics ranging the geography of Latin America to myriad topics dealing with its theatre. Workshops included a focus on theatrical translation by Phyllis Zatlin, psychoanalysis and theatre theory by Gustavo Geirola, classroom uses for acting and its benefits in helping students develop Spanish skills by Mónica Botta and Francine A'Ness, and a focus on masks and "expresión plástica-corporal" by Lowell Fiet. Playwright roundtables included Orlando Cajamarca from Colombia, Gabriel Peveroni from Uruguay, Aravind Enrique Adyanthaya from Puerto Rico, Reynaldo Disla from the Dominican Republic, Kimberly del Busto and 
Frank Disla from the U.S. (he is from the Dominican Republic, but now hails from New Jersey, and spoke on US-Latino theatre), Bárbara Colio, Alberto Lomnitz, and Manuel Talavera from Mexico, and Eduardo Rovner, Héctor Levy-Daniel, and Cristina Merelli from Argentina. The plenary presentations were delivered by Jean Graham-Jones ("Un vacío crítico: los traslados al norte del teatro argentino") and Jorge Huerta ("From the Margins to the Mainstream: US Latina/o Theatre in the U.S.). Two other sessions were on a par with plenary sessions - a presentation by Migdalia Cruz on her theatre, and the homage to Emilio Carballido, with tributes and memories from Jacqueline Bixler, Beatriz Rizk, Luis Martín, Héctor Herrera, and a video produced by Gisel Amezcua.

To my critical eye, the best of the main stage productions was i¿Quién te entiende?!, written and directed by Alberto Lomnitz, and performed by members of Seña y Verbo, Mexico's deaf theatre company. As Lomnitz explained in his roundtable session, this play was the result of an extensive series of interviews he conducted with a trio of deaf people in Mexico City. Based on his interviews, the play represented the essentials of their lives. A pair of deaf actors, Roberto de Loera and Lucila Olalde, along with Haydée Boetto, a hearing and speaking actor, played the parts of a trio of friends who got together to talk about their friends. Intermittently as they told stories about their friends, they would launch into an extensive series of meta-representations,

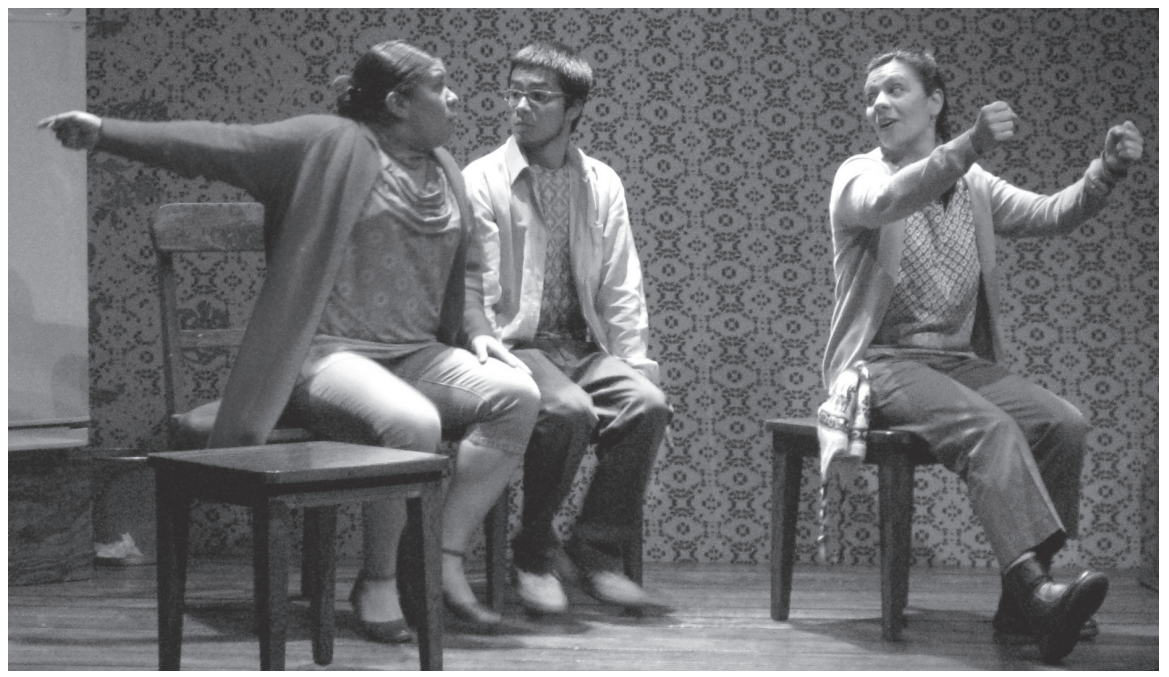

¿¿Quién te entiende?! Photo: Christopher Wells (in Mexico City) 


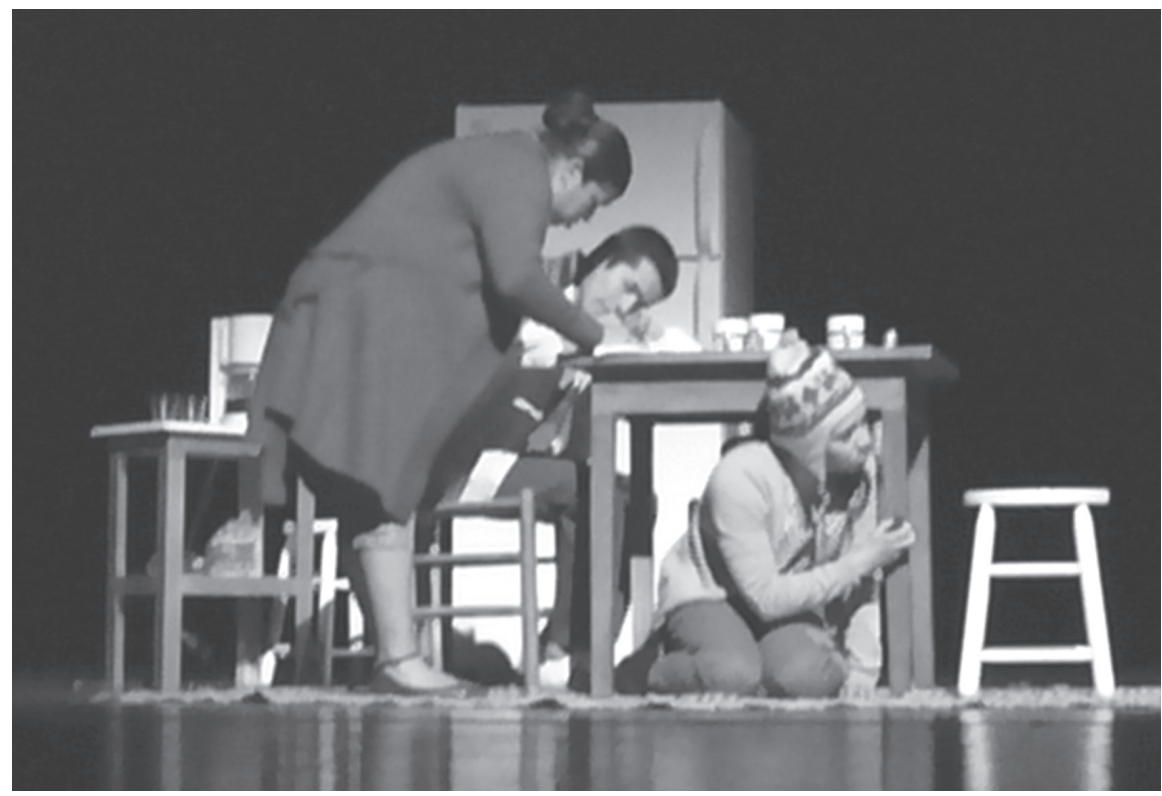

¿¿Quién te entiende?! Photo: Timothy Compton

taking on numerous roles, always returning to their original roles as friends. Olalde, for example, played more than 20 roles, ranging from a variety of friends, worker in a factory, teacher, actor in a movie, spectator at a movie, actor in a play, spectator at a play, parents, a child, a cousin, kidnapper, and so forth. De Loera and Boetto also played many roles, although I thought Olalde's range of characters was particularly impressive. The play hinged on the actors' ability to switch clearly and quickly from role to role so that the audience would be able to follow along with them. And the actors met the challenge brilliantly, relying almost entirely on body and facial expression, complemented occasionally by slight changes in their accessories. Boetto completed the transformation into Federico (several times), for example, by donning an Andean cap, while de Loera topped off his acting as a teacher by wearing glasses. I found it particularly delicious when, in a dazzling scene, the only hearing actor played the part of a deaf individual on his first day at work, while the deaf actors played the parts of hearing supervisors. In another memorable scene, the deaf actors became a pair of signing dictionaries, one of which translated Spanish into standard Mexican Sign Language, while the other translated into homemade signs. In both of these scenes, as with numerous scenes in the play, the theatrics were top-notch, making the play 
very entertaining at the same time that it gave considerable insight into the world and culture of the deaf. Many times spectators were immersed into the world of signs and a lack of sounds, as the play had them experience a touch of the deaf experience. Although hearing the stories of the three individuals in the play would undoubtedly have been interesting, the role playing made the stories spring to life in a delightful way. Boetto was the guide during the play, speaking directly to the audience as if talking to a friend, and interpreting the signs of the other actors. The set was minimal - a kitchen with a table and chairs -, but at times the actors used parts of the sparse set in clever ways, for example stacking chairs to create a machine in a workplace. The lighting was ambitious for a festival performance, with myriad changes to enhance the metatheatrics, and in most cases it was very effective. Finally, the play featured beautiful music composed specifically for this play by renowned Mexican composer and jazz musician Eugenio Toussaint. Some at the festival thought the play went a little too long (it ran 1 hour, 46 minutes). As it turned out, so did the actors and the director. Their usual performance venue is a very intimate theatre, with spectators a maximum of 6-7 rows away, and in adapting the play to the large Haymarket Theater in Blacksburg, with dozens of rows of spectators, they said they made everything bigger and it simply took longer than it ever had. Other spectators said they were delighted the play was long since they thoroughly enjoyed it and learned from it.

Quisimos tanto a Lydia was written and directed by Aravind Enrique Adyanthaya. He explained in the playwright roundtable that this play refers to Lydia Echevarría, an actress from an immensely popular television program he remembers vividly from growing up in Puerto Rico. Lydia starred in the program with her husband, Luis Vigoreaux, who was later convicted of her murder. Adyanthaya presided rather visibly over the event, personally inviting and seating some of the spectators on the sides of the stage, giving orders to the actors to commence, showing up from time to time on stage to help with props, and undoubtedly responding backstage to Instant Messages sent to Lydia by audience members at the conclusion of the play. This play did not pretend to review Lydia's life or even represent her, but presented a breakneck series of images, many of them imaginative, absurd, and surreal. The overall message seemed to be that television delivers a disjointed and absurd concatenation of images. The barrage of images began even prior to the play, as images from the old TV program played on a large on-stage screen. Some of the memorable images from the play included scenes in which actors performed with their trousers at their ankles, a woman read 
Cortázar ("Queremos tanto a Glenda," of course) holding the book high in the air with her feet, a masked all-star wrestler loudly imparted vengeance, a camera having an enormous Pepsi cup as a lens projected live stage images (at the back of the stage), characters tried to climb a greased pole, actors grinned from home-spun TV sets (of cardboard) they wore over their heads, and so forth. The actors were phenomenal in their timing and instant role changes. This play was assuredly memorable, although bizarre and chaotic.

Two plays by Argentine playwrights were performed. Cristina Merelli wrote and directed La culpa la tuvo el tranvía. Winner of the first George Woodyard Premio de Teatro Latinoamericano, this play featured the incredibly energetic acting of Gladys Torres, which contrasted markedly with the staid, dignified reading performances from five conference participants who read their lines from humorously oversized books while wearing bathrobes and slippers. As the five read a story about a melodramatic love story from colonial times, Torres had fun with the story, acting out parts of it, commenting on it, expanding on it, and savoring parts of it. Often she was hysterically funny, while at other times her antics bordered on irritating. Curiously, her back was to the audience the entire play, which caused considerable debate among some of the congresistas as to the technique's merits.

Eduardo Rovner wrote Volvió una noche, and Leticia Parra directed it in a performance done by the Tecnológico de Monterrey. This delicious comedy centered on the posthumous visits of a character's mother to him prior to his wedding. The fun of the play included observing the character's disbelief and then chagrin at his mother's presence, trying to hide her from his friends and fiancé, and wondering if he was going crazy. The fun multiplied because other characters could not see the deceased, so they assuredly thought he was going crazy. The costumes of the dead characters were memorable - overstuffed and metallic with completely painted faces. Some of the acting was overdramatic to the point of silliness, as were some of the sound effects, but overall this was a very enjoyable play.

Carlos Canales wrote Se formó la rumba, and Benjamín Guzmán directed María Paulino in it. This was a very short but scathing play decrying the cycle of abuse of women by men. The most outstanding element of this play was a clever role-reversal, placing into the mouth of a woman horrid abusive language normally used by abusive men.

The festival included the final performance of Abingdon Square by the Virginia Tech Department of Theatre Arts. Written by Maria Irene Fornes and directed by Robert H. Leonard, it was a beautiful play set in the upper 
class south of the United States in the early 1900s. It included elegant period costumes, a stately set, loving lighting, sweeping music between scenes, and proper, styled acting. Everything about this performance was of the highest quality, and it delivered a real feel for a place and time. The strangeness of the relationship between a 15-year-old girl and the older man who married her was vividly communicated, as were the huge emotions related to her infidelity and the resentments that ensued.

I managed to see two of the dramatic readings. Quince para cuartenta was written by Claudia Barrionuevo of Costa Rica and performed by Deb Cohen, Margarita Vargas, Janis Krugh, and Elaine Miller. It focused on an abundance of themes, among them the place of women in society, divorce, middle age and aging, and sexual liberation, all in the conversations of four women in their 40s. The dialogue was poignant and funny and audience members obviously connected with the play's topics. Parrita y sus verdugos, written by Guillermo Schmidhuber, was performed by Benjamín Guzmán, Luis Martín, and Olga Martha Peña Doria. Set in a contemporary Mexican prison, Parrita stems from actual events from recent Mexican history in which an innocent man was wrongfully imprisoned. I missed the dramatic reading of Hurricane in a Glass, by Kimberly del Busto and performed by students and faculty from Virginia Tech.

Finally, a very small group of spectators (thank goodness not all the invitees attended, for lack of space) was treated to clandestine performance of a play performed in room 231 of the Holiday Inn by Felipe Galván, who was also the author and director of the play. Galván has performed this play many times as street theatre in Mexico, often as part of political demonstrations. It focused on the sad state of a corrupt, non-responsive government in a country called "Estados Unidos Nahuamericanos," which was clearly Mexico, and lamented the plight of Nahuamericano masses. It was an effective reminder that not all theatre performances in Latin America happen in locales built for theatre, and not all are advertised through conventional means.

The rich tradition of Latin American Theatre Today now includes an immensely successful chapter held in Blacksburg, Virginia.

Northern Michigan University 